\title{
Aneurisma de la Arteria Pulmonar: Un hallazgo incidental
}

\author{
Pulmonary Artery Aneurysm as an incidental finding
}

Mujer de 92 años de edad que consulta por disnea con algunas semanas de evolución y tos seca. Presentaba también anorexia y náuseas. Entre los antecedentes personales se destacan fibrilación auricular, depresión, hipertensión arterial y fracturas costales múltiples con dos meses de evolución.

A la observación por el clínico la enferma se encontraba sin fiebre, hemodinámicamente estable y con buenas saturaciones de oxigeno. Incremento de la frecuencia respiratoria. A la auscultación cardiaca arritmia sin soplo. En la gasometría arterial pH 7.43 con paCO2 $38 \mathrm{mmHg}$ y paO2 $72 \mathrm{mmHg}$. Lactato de 0.7 $\mathrm{mmol} / \mathrm{L}$, bicarbonato de $25.2 \mathrm{mmol} / \mathrm{L}$ y saturación de oxigeno de

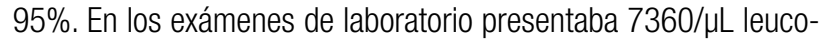
citos, 65,2\% de neutrófilos, D-Dímero 8458 ng/ml, PCR 0,2 mg/ dL. lones de la sangre, función renal, hepática y pruebas de coagulación sin alteraciones. La radiografía de tórax presentaba un desvío de la tráquea hacia la derecha. En la angio-TC de tórax "no se han observado señales de tromboembolia pulmonar, sin embargo, presentaba un derrame pericárdico con cerca de 1,3 $\mathrm{cm}$, una dilatación aneurismática de la aorta ascendente con $6 \mathrm{~cm}$ y una dilatación del tronco de la pulmonar con $4 \mathrm{~cm}$ y sus ramas derecha y izquierda".

Según la literatura el aneurisma de la arteria pulmonar es más raro que el aneurisma de la arteria aorta. Puede asociarse a infecciones, anomalías vasculares, hipertensión pulmonar primaria, vasculitis, en particular a la enfermedad de Beçhet, enfermedades del tejido conjuntivo y síndrome de Marfan (a semejanza de lo que ocurre con el aneurisma de la arteria aorta). Puede también ser idiopático. Los síntomas asociados suelen ser disnea, tos, hemoptisis, palpitaciones y/o dolor torácico. El tratamiento y su evolución dependen de la situación clínica a la que se asocian. Sin embargo el tratamiento inicial suele ser conservador.

En este caso se optó por un tratamiento conservador.

\section{Diagnóstico: Aneurisma de la Arteria Pulmonar}

Cátia Andreia Rego Lopes Pereira, Amilcar Lima Silva Centro Hospitalar Universitário de Coimbra

Correspondencia: catiapereira30@hotmail.com

Como citar este artículo: Rego Lopes Pereira CA., Lima Silva A.

Aneurisma de la Arteria Pulmonar: Un hallazgo incidental. Galicia Clin 2016; 77 (1): 43

Recibido: 25/10/2015; Aceptado: 31/10/2015
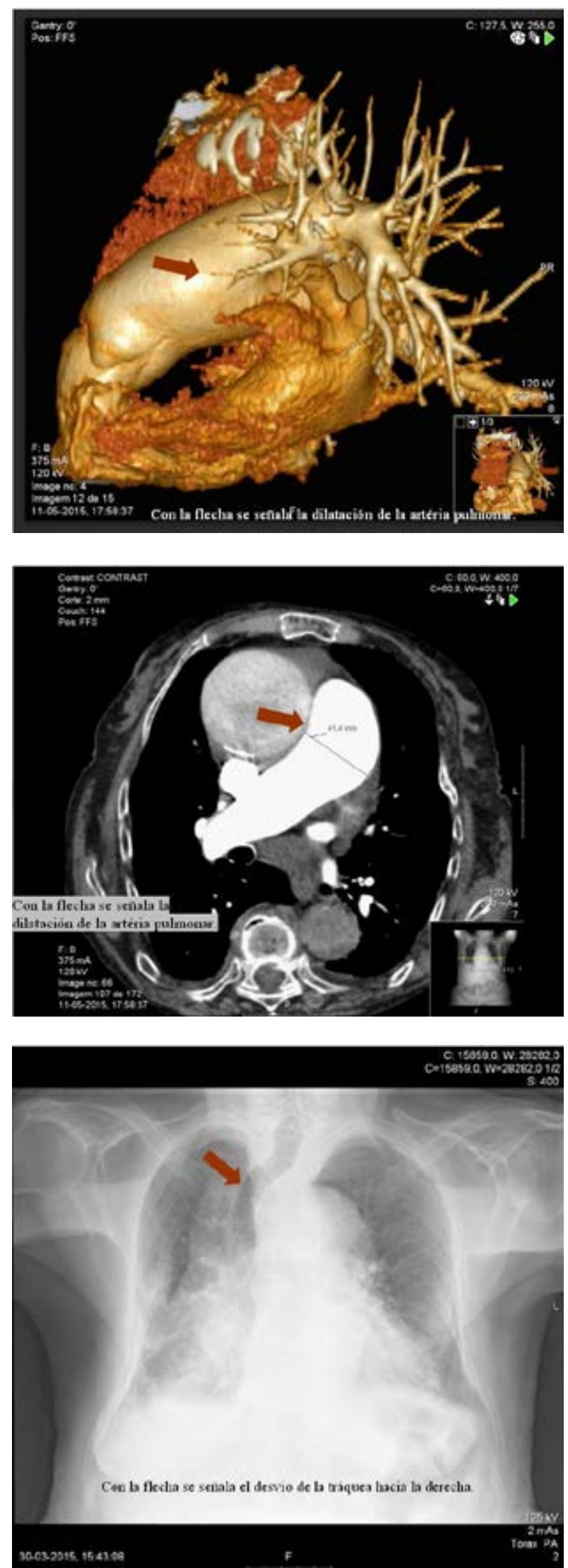